\title{
Lisa Adkins, Melinda Cooper, and Martijn Konings: The Asset Economy
}

\author{
Julia Cook ${ }^{1}$
}

Received: 29 March 2021 /Revised: 12 April 2021 / Accepted: 14 April 2021 /

Published online: 21 April 2021

(C) The Author(s), under exclusive licence to Springer Nature Singapore Pte Ltd. 2021

Adkins, Cooper, and Konings present a new way of thinking about class, inequality, and stratification. This effort is rooted in Piketty's (2014) now famous claim that the growth of asset values outstripping the growth of the economy in general, and wages in particular, is the key driving factor underpinning rising inequalities. However, Adkins, Cooper, and Konings go beyond Piketty's dogmatic focus on the top one percent of the wealth strata to instead consider the broader social impact of such developments. Specifically, they contend that asset appreciation has redrawn the social structure to the extent that asset ownership has now eclipsed employment as the key determinant of class position in AngloAmerican societies.

This brand of large-scale, systemic thinking is the key strength of the book. Adkins, Cooper, and Konings place financial and social developments into context by, for instance, identifying the effects of quantitative easing not as an isolated cause of property price inflation, but as the latest in a swathe of financial policies that have been pursued since the 1980s. Using this large-scale vision, they trace a historical narrative that has roots in the taxation policies of the Reagan era in the USA and Keating's introduction of negative gearing in Australia. They provide a convincing explanation of how investment income came to be taxed at a much lower rate than wage-based income, how this impacted upon distribution of wealth and income, and how the short to midterm effects of these developments were cushioned by home ownership

Julia Cook

julia.cook@newcastle.edu.au

1 School of Humanities and Social Science, University of Newcastle, Callaghan, New South Wales, Australia 
democratization policies which built upon the accumulated legacy of post-war housing policies.

The narrative that the authors build is of particularly utility for considering the plight of the millennial generation, for whom the price of entry to the property market lies increasingly out of reach. Adkins, Cooper, and Konings use this narrative to support the argument that property inflation and the social and economic processes resulting from it do not simply contribute to inequality and stratification - they produce a new logic of inequality which reshapes the class structure. As the key subjects of this new experience of class, inequality, and stratification, the millennial generation find themselves dependent on families to provide strategically timed intergenerational transfers of wealth. This dynamic is identified by the authors as a mixture of hypercapitalist logics of financialization with feudal logics of inheritance - a formulation that provides significant fuel for the imaginations of researchers of class and intergenerational inequality.

Adkins, Cooper, and Konings systematize their insights about class structures by developing a typology of class for the asset economy (see also Adkins et al. 2019). They draw from elements of existing models of class while contending that their focus on work and employment leaves them ill-equipped to account for the rising significance of assets for wealth accumulation. In answer to this, the authors propose a class schema that is "analogous to Marxist and Weberian schemes" but also identifies asset ownership as the key distributor and driver of life chances (p. 54). Although it is developed with reference to the Australian context, the schema speaks to a broader Anglo-American context that has much in common with the Australian experience of property value inflation, and the policy architecture that made it possible. While this schema offers a detailed and generative account of how individuals are positioned within a hierarchy of asset ownership, it is curious that it focuses primarily on economic capital and does not attend in detail to social and cultural dimensions of class despite the authors' acknowledgement of the value of Bourdieu's broadening of the concept of capital a few pages prior.

Both Adkins and Konings have worked extensively with the concept of temporality and its relationship to credit and debt. In this text, they draw on this work to claim that the asset economy structures class by separating those who are locked into the short temporal horizons of the commodity economy, and those who participate in the longer horizons of speculative asset valuation in the asset economy. The ability to participate in the asset economy is contingent on one's capacity to marshal resources to pay the price of entry into the asset economy, and to maintain ongoing access to liquidity in order to service debts. For young 
adults who have now been locked out of entering into the asset economy solely through the power of their own earnings, the key to gaining liquidity and entering into the asset economy thus lies in financial transfers from parents or other older relatives. It is in this way, the authors claim, that the family now operates as a key source of economic security. Again, for this reason, it is curious that the social capital (family relationships) that facilitates the transfer of economic capital is not more prominent in the schema of class.

Adkins, Cooper, and Konings' central thesis is that analyzing the problem of asset-based inequality using an understanding of inequality that centers on work does not allow this dilemma to be appropriately understood or addressed. However, as they highlight, the problem of asset-based inequality is also one of policy lock-in, and of a dearth of political and public will for change that may compromise the stability of economies and lives built on asset-based wealth. There is also a cultural dimension to this dilemma, enshrined most notably in the indefatigable "Australian dream" of home ownership that has been detailed elsewhere (Bruce and Kelly 2013). Writing this review on the day that the Australian Federal Government's "JobKeeper" income support program ends amid a flurry of news stories about a renewed boom in property prices, the analysis evokes a more recent crisis and reads as a grim prediction of what the coming years may bring. Indeed, as Adkins, Cooper, and Konings note in the preface to the book-written as the COVID-19 pandemic began to unfold- "the political stakes will be even higher this time" (p. 6). In articulating the deep roots of the asset economy, this book constitutes essential reading for anyone engaged with the mechanisms shaping inequality in Anglo-American states.

\section{Declarations}

Conflict of interest The author declares no competing interests.

\section{References}

Adkins L, Cooper M, Konings M (2019) Class in the 21st century: asset inflation and the new logic of inequality. Environ Plan A: Economy and Space. https://doi.org/10.1177/0308518X19873673

Bruce M, Kelly S (2013) Expectations, identity and affordability: the housing dreams of Australia's generation Y. Hous| Theory Soc 30(4):416-432. https://doi.org/10.1080/14036096.2013.767279

Piketty T (2014) Capital in the twenty-first century. Harvard University Press, Cambridge 